\title{
Innovative Approaches, Tools and Visualization Techniques for Analysing Land Use Structures and Dynamics of Cities and Regions (Editorial)
}

\author{
Robert Hecht ${ }^{1}$ (D) $\cdot$ Martin Behnisch ${ }^{1}$ (D) Hendrik Herold $^{1}$ (D)
}

Accepted: 27 July 2020 / Published online: 10 August 2020

(C) The Author(s) 2020

\begin{abstract}
Geospatial analysis and visualisation can be used to gain knowledge about land use structure and its changes on different spatial scales, which in turn is key to unlock the potential for sustainable land use development. This editorial provides a frame to a set of papers of the topical collection "Innovative approaches, tools and visualization techniques for analyzing land use structures and dynamics of cities and regions", which was initiated in conjunction with the 2017 International Land Use Symposium taken place in Dresden, Germany. It first introduces current, urging land use, development and management challenges. Further on, the editorial presents the individual contributions and reflects their affiliation to the themes "Mapping and Monitoring Approaches" and "Planning, Decision Support and Participation". Although the objectives, methods and underlying data used in the papers of this topical collection greatly vary, as pieces of a puzzle they contribute to a better analysis and understanding of current and future land use structures and dynamics of cities and regions.
\end{abstract}

Keywords Land use structures · Spatial planning · Urban development · Urban dynamics · Decision support · Monitoring · Mapping

Sustainable land use development is a pressing challenge all over the world. As the world's population continues to grow, more and more people will be living in cities. Land as a finite and shrinking resource must be treated with particular care. Urban areas are currently expanding at rates twice as high on average as population growth, covering about $0.5 \%$ of the planet's land area (Angel et al. 2011). Despite their relatively small area, urban land cover change is driving global environmental change, threatening biodiversity and reducing ecosystem productivity through loss of habitat, biomass and carbon storage (Seto et al. 2012). Forests, for example, provide habitats for millions of species and are an important producer of clean air and freshwater and play a crucial role in mitigating

Robert Hecht

r.hecht@ioer.de

Martin Behnisch

m.behnisch@ioer.de

Hendrik Herold

h.herold@ioer.de

1 Leibniz Institute of Ecological Urban and Regional Development, Dresden, Saxony, Germany climate change (Canadell and Raupach 2008). But, these areas are in danger. Urbanization and the associated international demand for agricultural products for food lead to deforestation (Defries et al. 2010). The demand for land, food and energy leads to land use conflicts, especially severe along production systems and supply chains and in peripheries and hinterlands. Haber (2007:363) talks in this context about so-called "ecological traps", which are a complex environmental problem and, in addition, to climate change and the loss of biodiversity, a major threat to humanity and the planet.

We are currently experiencing unprecedented soil degradation and the loss of arable land (Döös 2002). Droughts and desertification are increasing every year, impoverishing the population and leading to the extinction of endangered animal and plant species. The SDGs established by the UN (United Nations 2020) aim to preserve and restore the use of terrestrial ecosystems such as forests, wetlands, arid areas and mountains. Measures must be taken urgently to reduce the loss of natural habitats and biodiversity, which are part of our common heritage (Goal 15, United Nations 2020). This requires a responsible land policy and management with many good and creative ideas, innovative instruments, meaningful measures and powerful actors at all decision-making levels. Spatial modelling and visualization of land use and its dynamics by 
means of suitable indicators play a central role, because they provide basic information for meaningful decision making. Only in this way, the gradual land change, such as caused by urban sprawl, can be brought into the consciousness of citizens and politicians (Rindfuss et al. 2004; Siedentop and Fina 2010; Herold 2018). The availability and quality of geodata and information services are constantly increasing. With the Global Human Settlement Layer (GHSL), for example, open data on the human environment are available with global coverage (Pesaresi et al. 2016). This data enables global analyses of the growth of built-up areas and population over the last 40 years at a new level of detail. However, the processing of large amounts of data (Big Data) lead to new challenges (Jiang and Shekhar 2017; Li et al. 2016; Lee and Kang 2015).

Introducing and discussing innovative approaches, tools and visualization techniques for analysing land use/cover structures and dynamics of cities and regions was the intention of this topical collection. The collection was initiated in conjunction with the International Land Use Symposium held in Dresden, Germany (http://ilus2017.ioer.info). It was aimed at academics in the fields of spatial sciences, information sciences, computer science, environmental studies, geography, cartography, GIScience, urban planning and architecture. Contributions focus on the question how recent developments in geospatial analysis and visualization can lead to better indicators, tools and decision support for urban and landscape planning.

The topical collection consists of seven contributions subdivided into the two sections: mapping and monitoring approaches (1) and planning, decision support and participation (2). The contributions were subjected to a rigorous scientific peer review and each of which offers a new approach, tool or visualization technique for analysing and understanding land use structures and/or its dynamics in their many facets.

\section{Mapping and Monitoring Approaches}

Four contributions propose novel mapping and monitoring approaches for certain land use and cover phenomena such as soil sealing (Schmidt and Barron 2020), building density (Sikder et al. 2019), urban green volume (Frick and Tervooren 2019) and land surface temperatures (Rongali et al. 2018).

Schmidt and Barron (2020) present a GIS-based mapping approach of impervious surfaces combining vector data (municipal cadaster, green area cadaster and OSM data) and highresolution airborne imagery (coloured infrared imagery with a spatial resolution of $10 \mathrm{~cm}$ ). The German city of Mannheim serves as a testbed for the representation of pervious and impervious surfaces. Misclassifications, which are influenced by unsatisfactory vector data and temporal discrepancies between aerial photographs and cadastral data, can be observed mainly on parking lots, railway tracks, allotment gardens, cemeteries and sports fields. The paper illustrates very clearly the problem of developing a consistent and reliable mapping approach for impervious surfaces, which will subsequently support the comparison of cities. Especially from the perspective of national and international urban statistics and against the background of sustainable land management, it is essential to focus on a coherent approach.

Up-to-date spatial data on urban infrastructures as base for sustainable decision making and urban planning isparticularly for the many fast-growing cities in developing countries-both valuable and rare. To address this challenge, Sikder et al. (2019) present a spatial analysis approach to gain knowledge about the building structure of Dhaka, Bangladesh, that is among the fastest-growing cities in South Asia and, according to United Nations (2008), expected to become the world's third largest megacity. The analysis was based on Moran's I and Gini indices applied to a public sector building data set. The variability of the estimated spatial statistics in buildings and their use is interpreted according to clustering patterns with the location of the central business district (CBD) as well as the public bus transit infrastructure (routes and stops). The insights gained will most certainly support local data-driven planning and decision making; important information on uncertainties and model sensitivities, however, are still subject to further research.

In addition to the building structure, green infrastructure is of central importance, as it is significant for many aspects of urban life and urban planning. Frick and Tervooren (2019) present a framework for capturing and monitoring urban green volume with high spatial resolution based on multi-temporal and multi-sensor remote-sensing data, in particular aerial stereo images, QuickBird, WorldView 2 and 3, Sentinel 2, HRSC, as well as LIDAR. Based on the example of a case study in Potsdam, Germany, it was shown that this approach can be used to build long time series over 25 years. The results therefore offer the opportunity to analyse urban development in detail with regard to green infrastructure and to better understand underlying urban planning processes. In addition, the data provide a good basis for adaptation to climate change, for example, to avoid heat stress. Such data also provide a good planning basis for climate change adaptation efforts, for example, in the planning of urban green spaces in connection with the prevention of heat stress.

Global climate change poses risks to land-based human systems and ecosystems (IPCC 2020). The relationship between land use and climate is complex. On the one hand, land cover (shaped by land use practices) has a long-term effect on the global concentration of greenhouse gases and is thus an important driver of climate change. On the other hand, a changing climate can lead to changes in land use/land cover if, for example, farmers have to adapt their traditional crops, the population flees because of a lack of water or the water level rises, leading to conflicts with settlements in coastal 
areas. Against this background, Rongali et al. (2018) present an approach to mapping the land surface temperature (LST) using Landsat 8 Thermal Infrared Data. A validation on an area in India (Beas River basin in India) showed that the estimates differ from the true measured air temperature by up to $5{ }^{\circ} \mathrm{C}$ at a maximum.

\section{Planning, Decision Support and Participation}

Three other contributions are very practical and present tools, frameworks and processes in the context of planning, decision support and participation.

Despite the trend towards concentrated urban population growth, many cities are suffering from severe depopulation (or shrinkage), which is leading to increased vacancies and the abandonment of buildings. As a result, cities are now looking for ways to more intelligently inventory and manage shrinking neighbourhoods through "Smart Shrinkage". The contribution of Newman et al. (2018) examines current approaches to managing empty urban land through case evaluations and uses the results to develop an applied strategy of smart shrinkage for the conversion of empty land. Using land use forecasts, future development is first modelled and a GISsupported development suitability model is used to evaluate options for action down to the parcel level. The results indicate that the forecasts require the introduction of policy mechanisms that allow land to be converted for non-residential purposes in a way that is compatible with existing demand.

Strategic spatial plans serve to plan the future development of urban regions. A great challenge is the appropriate cartographic representation. The presentation of information in spatial planning documents rarely allows for clear visualisation, as the planning intentions are often very fragmented into text, graphics, tables, diagrams and maps. Palka et al. (2018), therefore, present a visualization approach that allows planning intentions derived from strategic spatial plans to be translated into new pixel-based synthetic maps that enable a better understanding of spatiality. Their methodological approach is demonstrated with the case study Copenhagen, Denmark. By visualising the very heterogeneous data found in strategic spatial plans, the proposed approach offers an opportunity to establish a new link between the objectives and means of spatial planning and their spatiality. As the authors point out, this could reduce the gap between spatial planning and land change modelling by translating the heterogeneous information of spatial planning documents into meaningful and exploitable data.

In addition to a good communication of planning intentions, participation plays an increasingly important role. This is particularly important in the context of urban development, where the needs of a large number and diversity of people must be met. Digital tools are used to support collaborative design processes. The contribution by Hofmann et al. (2020) addresses the issue of evaluating such participation processes in order to prove that the necessary costs and efforts are justified. To this end, evaluation criteria are developed which, as the authors note, are also used as indicators to assess the value of the process in its initial phase in order to avoid failures and increase the democratic value from the very beginning.

On behalf of all authors, the guest editors hope that this topical collection in the Springer Journal of Geovisualization and Spatial Analysis will contribute to promoting interest in this specific topic. The contributions have shown how diverse the approaches, used methods and data used are. Each individual contribution of the topical collection forms a piece of a puzzle to better describe, analyse and understand land use structures and dynamics of cities and regions.

Acknowledgements We thank all authors for their high-quality contributions as well as the reviewers for their valuable advice to ensure the scientific quality of the individual contributions. We would also like to thank the editors-in-chief, especially Haowen Yan and Michael Peterson, for their support in the process of making this topical collection possible.

Funding Information Open Access funding provided by Projekt DEAL. This research received no external funding.

\section{Compliance with Ethical Standards}

All accepted principles of ethical and professional conduct have been followed during this research in accordance with Springer's standards.

Conflict of Interest The authors declare that they have no conflict of interest.

Ethical Approval This manuscript has not been published, accepted for publication, or under editorial review for publication elsewhere.

Informed Consent The authors have given the informed consent to publish this article in the Journal of Geovisualization and Spatial Analysis if accepted.

Open Access This article is licensed under a Creative Commons Attribution 4.0 International License, which permits use, sharing, adaptation, distribution and reproduction in any medium or format, as long as you give appropriate credit to the original author(s) and the source, provide a link to the Creative Commons licence, and indicate if changes were made. The images or other third party material in this article are included in the article's Creative Commons licence, unless indicated otherwise in a credit line to the material. If material is not included in the article's Creative Commons licence and your intended use is not permitted by statutory regulation or exceeds the permitted use, you will need to obtain permission directly from the copyright holder. To view a copy of this licence, visit http://creativecommons.org/licenses/by/4.0/.

\section{References}

Angel S, Parent J, Civco DL, Blei A, Potere D (2011) The dimensions of global urban expansion: estimates and projections for all countries, 
2000-2050. Prog Plan 75:53-107. https://doi.org/10.1016/j. progress.2011.04.001

Canadell JG, Raupach MR (2008) Managing forests for climate change mitigation. Science 320:1456-1457. https://doi.org/10.1126/ science. 1155458

DeFries R, Rudel T, Uriarte M et al (2010) Deforestation driven by urban population growth and agricultural trade in the twenty-first century. Nat Geosci 3:178-181. https://doi.org/10.1038/ngeo756

Döös BR (2002) Population growth and loss of arable land. Glob Environ Chang 12(4):303-311. https://doi.org/10.1016/S0959-3780(02) 00043-2

Frick A, Tervooren S (2019) A framework for the long-term monitoring of urban green volume based on multi-temporal and multi-sensoral remote sensing data. J Geovis Spat Anal 3(6). https://doi.org/10. 1007/s41651-019-0030-5

Haber W (2007) Energy, food, and land - the ecological traps of humankind. Environ Sci Pollut Res Int 14:359-365. https://doi.org/10. 1065/espr2007.09.449

Herold H (2018) Geoinformation from the past - computational retrieval and retrospective monitoring of historical land use. Springer, Wiesbaden. https://doi.org/10.1007/978-3-658-20570-6

Hofmann M, Münster S, Noennig JR (2020) A theoretical framework for the evaluation of massive digital participation systems in urban planning. J Geovis Spat Anal 4(3). https://doi.org/10.1007/s41651-019$0040-3$

IPCC (2020) Climate change and land: an IPCC special report on climate change, desertification, land degradation, sustainable land management, food security, and greenhouse gas fluxes in terrestrial ecosystems. Intergovernmental Panel on Climate Change. https://www. ipcc.ch/site/assets/uploads/sites/4/2020/02/SPM_Updated-Jan20. pdf. Accessed 20 June 2020

Jiang Z, Shekhar S (2017) Spatial big data science - classification techniques for earth observation imagery. Springer, Cham. https://doi. org/10.1007/978-3-319-60195-3

Lee JG, Kang M (2015) Geospatial big data: challenges and opportunities. Big Data Res 2(2):74-81. https://doi.org/10.1016/j.bdr.2015. 01.003

Li S, Dragicevic S, Castro FA, Sester M, Winter S, Coltekin A, Pettit C, Jiang B, Haworth J, Stein A, Cheng T (2016) Geospatial big data handling theory and methods: a review and research challenges. ISPRS J Photogramm Remote Sens 115:119-133. https://doi.org/ 10.1016/j.isprsjprs.2015.10.012

Newman G, Hollander JB, Lee J, Gu D, Kim B, Lee RJ, Horney JA, Bearfield D, Li Y (2018) Smarter shrinkage: a neighborhood-scaled rightsizing strategy based on land use dynamics. J Geovis Spat Anal 2(11). https://doi.org/10.1007/s41651-018-0018-6

Palka G, Grădinaru SR, Jørgensen G, Hersperger AM (2018) Visualizing planning intentions: from heterogeneous information to maps. J Geovis Spat Anal 2(16). https://doi.org/10. 1007/s41651-018-0023-9

Pesaresi M, Melchiorri M, Siragusa A, Kemper T (2016) Atlas of the human planet 2016. Mapping Human Presence on Earth with the Global Human Settlement Layer. Science for Policy report, Joint Research Centre (JRC). http://publications.jrc.ec.europa.eu/ repository/bitstream/JRC103150/atlas\%20of\%20the\%20human\% 20planet_2016_online.pdf. Accessed 20 June 2020

Rindfuss RR, Walsh SJ, Turner BL, Fox J, Mishra V (2004) Developing a science of land change: challenges and methodological issues. PNAS 101(39):13976-13981. https://doi.org/10.1073/pnas. 0401545101

Rongali G, Keshari AK, Gosain AK, Khosa R (2018) Split-window algorithm for retrieval of land surface temperature using Landsat 8 thermal infrared data. J Geovis Spat Anal 2(14). https://doi.org/10. 1007/s41651-018-0021-y

Schmidt S, Barron C (2020) Mapping impervious surfaces precisely - a GIS-based methodology combining vector data and high-resolution airborne imagery. J Geovis Spat Anal 4(14). https://doi.org/10.1007/ s41651-020-00055-6

Seto KC, Güneralp B, Hutyra LR (2012) Global forecasts of urban expansion to 2030. PNAS 109 (40):16083-16088. https://doi.org/10. 1073/pnas.1211658109

Siedentop S, Fina S (2010) Monitoring urban sprawl in Germany: towards a GIS-based measurement and assessment approach. J Land Use Sci 5(2):73-104. https://doi.org/10.1080/1747423X.2010. 481075

Sikder SK, Behnisch M, Herold H, Koetter T (2019) Geospatial analysis of building structures in megacity Dhaka: the use of spatial statistics for promoting data-driven decision-making. J Geovis Spat Anal 3(7). https://doi.org/10.1007/s41651-019-0029-y

UN (2008) World urbanization prospects: The 2007 revision. New York, USA

United Nations (2020) The Sustainable Development Goals Report 2020, United Nations Publications, New York. https://unstats.un.org/sdgs/ report/2020/ Accessed 20 June 2020

Publisher's Note Springer Nature remains neutral with regard to jurisdictional claims in published maps and institutional affiliations. 